\title{
HIGH HIV PREVALENCE AMONG LOW INCOME AND LABORERS IN THE DISTRICT OF PURBA MEDINIPUR, WEST BENGAL, INDIA
}

\author{
Biswas DK' ${ }^{1}$ Bhunia $\mathrm{R}^{2}$, Mishra $\mathrm{A}^{3}$ \\ 1 Dy. Chief Medical Officer of Health-II, District Purba Medinipur, West Bengal, India \\ 2 Field Epidemiology Training Programme, National Institute of Epidemiology, Chennai, India and District Tuberculosis \\ Officer, District Hooghly, West Bengal, India \\ 3 District Programme Manager for HIVIAIDS, District Purba Medinipur, West Bengal, India
}

\begin{abstract}
Introduction: There were limited data of "People Living with HIVIAIDS" (PLHA). The data of PLHA were analyzed in time, place and person and socio-economic status and recommended for prevention of HIV infection. Objective of study were to describe the PLHAs in term of time, place and person distribution and their socio-demographic status, to detect the mode of transmission of HIV and to recommend for prevention of spread HIV infection and social security.

Methodology: The information about socio-demographic status and exposure history of PLHAs since 2010 was collected. Data were analyzed by using Epi-info software.

Results: Among 329 PLHAs, 165 (50\%) were men and $42(13 \%)$ were children $<14$ years and they acquired HIV through blood transfusion 26 (62\%). A maximum 276 (84\%) PLHAs were age group 15 45 years. Out of 25 Community Block in district, maximum PLHAs were distributed at Tamluk Block 56 (17\%) followed by Paskura 43 (13\%). Of PLHAs, $246(75 \%)$ had family income rupees $\leq 2000.00$ per month and $138(38 \%)$ of them were laborer and $85(26 \%)$ home maker (house-wife). Highest $289(88 \%)$ of PLHAs acquired HIV through heterosexual route.
\end{abstract}

Conclusion: Heterosexual transmission of HIV showed among low income and laborer. The counseling for safe sex practice, employment people and social amenities were recommended.

Key words: Human Immunodeficiency Virus, Heterosexual, Purba Medinipur

\section{INTRODUCTION}

People living with Human Immunodeficiency Virus (HIV) were 33.4 million (range 31.1 million - 35.8 million) in 2008 , which was $20 \%$ higher than in $2000 .^{1}$ Around $68 \%$ of People Living with HIVIAIDS (PLHAs) were in Sub-Saharan Africa. ${ }^{2}$ It was estimated 270,000 new HIV infections in 2010 in South and South-East Asia. ${ }^{3}$ In India, 23.7 lakh people were living with HIV in 2009. ${ }^{4}$ Purba Medinipur district had159 new PLHAs (in 2010).

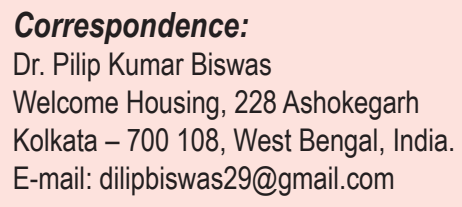

Here the prevalence of HIV in the district Purba Medinipur among the high risk group was more than $5 \%$ and among the antenatal mother was less than $1 \% .^{5}$

There was inadequate information about PLHAs in the district of Purba Medinipur, West Bengal, India. Total population of the district was $46,60,448$ (census 2001). ${ }^{6}$ The district situated at the eastern side of West Bengal and a long sea beach is situated at the southern side. Literacy rate of district was $88 \%$ and it was highest among the districts of West Bengal. The secondary data of PLHA in the district of Purba Medinipur, West Bengal, India were analyzed. 


\section{METHODOLOGY}

It was a descriptive study. In this study PLHAs were defined as those who had been tested positive for HIV (Rapid Test and ELESA test methods) by laboratory technician at different Integrated Counseling and Testing Centers (ICTC) during the year 2005 and 2010. There were 12 ICTC in the district.

All PLHAs identified at different ICTC in the district for study were included in the study. People of Purba Medinipur also diagnosed positive for HIV at government referral laboratories situated at Medical College Hospitals, Anti Retroviral Treatment (ART) center and Institute of Tropical Medicine, Kolkata were also included in this study. People diagnosed positive by laboratories of NonGovernment Hospital and private hospital were excluded for the study.

All the PLHAs had been enrolled in a data base of "SPARSHA" a Non- Government Organization (NGO). Data of PLHA from "SPARSHA" who work with PLHAs as project of "CARE \& SUPPORT" in the district were analyzed. The format of semi-structured questionnaires for collection of data were used. Questionnaires containing name, age, sex, address, socio-demographic characteristics, occupation, date of onset of symptoms and treatment history of PLHA. Social workers, working in this NGO had been engaged for collection of data.

Data of PLHAs were analyzed by of age, sex, education and socio-demographic status. The distribution of PLHAs was described according to their residential address situated at Community Blocks of district. The exposure history of patients were described. The data were analyzed as percent and proportion. Epi-info and MS excel for analysis of data were used. Data were analyzed as per family income. Those who have the family income of less than Rs: $2000 /$ month was called as Below Poverty Line (BPL) family (when people don't have money to even their day to day expense such as food, shelter, clothing etc).

\section{RESULTS}

Thirteen percent (42/329) of PLHA was age group of $1-14$ years, among them boys $74 \%$ (31/42) were maximum than the girls. Maximum PLHAs were young and adult (age15- 45 years) 276 (84\%). Among them $150(46 \%)$ age group of $15-30$ years and here woman were maximum $67 \%$ (100/150) than men. Thirty eight percent (126) were age group of 31-45 years, among them men were predominant $60 \%(75 / 126)$ than women.

Of total 329 PLHAs, 165 (50\%) were men and 164 $(50 \%)$ were women (Table 1 ).

Among the total PLHAs, $66 \%$ (216) were illiterate to $5^{\text {th }}$ standard, where maximum were female $70 \%$ (115), they were $26 \%$ (85) home maker by profession. Labor and migrant labors were $38 \%$ (128), among them men and women were $49 \%$ (80) and $29 \%$ (48) respectively. Female sex workers were only $2 \%(7)$, but truckers and student were $10 \%$ (34) and $11 \%$ (35) respectively. Maximum $75 \%$ (246) PLHAs had the family income of rupees $\leq 2000$ / per month (Table 1).

\begin{tabular}{|c|c|c|c|c|c|c|}
\hline $\begin{array}{l}\text { Table 1. PLHA s } \\
\text { Medinipur, } 2010\end{array}$ & tus in & the $c$ & istrict & & & \\
\hline Characteristics & $\begin{array}{c}M \\
(n=\end{array}$ & 65) & & & & \\
\hline Age (Years) & $\mathrm{n}$ & $\%$ & $\mathrm{n}$ & $\%$ & $\mathrm{n}$ & $\%$ \\
\hline Age Group & & & & & & \\
\hline $1-14$ & 31 & 19 & 11 & 7 & 42 & 13 \\
\hline $15-30$ & 50 & 30 & 100 & 61 & 150 & 46 \\
\hline $31-45$ & 75 & 46 & 51 & 31 & 126 & 38 \\
\hline $46-60$ & 8 & 5 & 0 & 0 & 8 & 2 \\
\hline$>61$ & 1 & 1 & 2 & 1 & 3 & 1 \\
\hline Education & & & & & & \\
\hline Illiterate & 15 & 9 & 18 & 11 & 33 & 10 \\
\hline $1^{\text {st }}-5^{\text {th }}$ Std & 86 & 52 & 97 & 59 & 183 & 56 \\
\hline $6^{\text {th }}-10$ th Std & 54 & 33 & 47 & 29 & 101 & 31 \\
\hline $11^{\text {th }}$-Graduate & 8 & 5 & 1 & 1 & 9 & 3 \\
\hline$>$ Post Graduate & 2 & 1 & 1 & 1 & 3 & 1 \\
\hline Occupation & & & & & & \\
\hline House wife & 0 & 0 & 85 & 52 & 85 & 26 \\
\hline Trucker & 33 & 20 & 1 & 1 & 34 & 10 \\
\hline Student & 25 & 15 & 10 & 6 & 35 & 11 \\
\hline Daily laborer & 51 & 31 & 46 & 28 & 97 & 29 \\
\hline Migrant laborer & 29 & 18 & 2 & 1 & 31 & 9 \\
\hline Business & 15 & 9 & 6 & 4 & 21 & 6 \\
\hline Services & 5 & 3 & 5 & 3 & 10 & 3 \\
\hline Unemployed & 7 & 4 & 2 & 1 & 9 & 3 \\
\hline Sex worker & 0 & 0 & 7 & 4 & 7 & 2 \\
\hline Family Income ( & upee) & & & & & \\
\hline$\leq$ Rs: 2000 & 114 & 69 & 132 & 81 & 246 & 75 \\
\hline > Rs: 2000 & 51 & 31 & 32 & 20 & 83 & 25 \\
\hline
\end{tabular}




\begin{tabular}{|l|c|c|c|c|c|c|c|c|c|}
\hline Table 2. Exposure history of PLHA in the district of Purba Medinipur, West Bengal, India 2010 \\
\hline \multicolumn{3}{|c|}{ Route of transmission } & \multicolumn{3}{|c|}{ Men } & \multicolumn{3}{c|}{ Women } & \multicolumn{4}{c|}{ Total } \\
\hline & $\mathrm{N}=165$ & $\%$ & $95 \% \mathrm{Cl}$ & $\mathrm{N}=164$ & $\%$ & $95 \% \mathrm{Cl}$ & $\mathbf{N}=329$ & $\%$ & $95 \% \mathrm{Cl}$ \\
\hline Heterosexual & 136 & 82 & $88-176$ & 153 & 93 & $97-188$ & 289 & 88 & $91-184$ \\
\hline Blood Transfusion & 13 & 8 & $13-34$ & 5 & 3 & $7-31$ & 18 & 5 & $9-33$ \\
\hline Parent to Child Transmission & 15 & 9 & $15-45$ & 6 & 4 & $8-41$ & 21 & 6 & $10-44$ \\
\hline Others & 1 & 1 & $3-60$ & 0 & 0 & $2-60$ & 1 & 1 & $2-60$ \\
\hline Total & 165 & 100 & & 164 & 100 & & 329 & 100 & \\
\hline
\end{tabular}

95\% Confidence Interval (Cl)

Among the total PLHAs, $88 \%$ (287) had history of getting infection through heterosexual route. Female were infected through heterosexual route more than male. $5 \%$ (18) of PLHAs had history of blood transfusion having thalassaemia. Parent to child transmission route was only $21(6 \%)$ (Table 2).

The district had four sub-divisions named Tamluk, Haldia, Contai and Egra. District head quarter was situated at Tamluk. Maximum 47\% (156) of PLHA cases were from the Tamluk Sub-division followed by Egra 19\% (62), Haldia 17\% (57) and Contai $17 \%$ (56). Migratory people were more in the district due to presence of large industries like Haldia Petro-chemical, Kolaghat Thermal Power Plant and attractive sea beach at Digha (Figure 1).

Maximum cases were from rural areas of the district such as Panskura-I, II, Tamluk, Sutahata, Nanda Kumar and Bhagwanpur-II blocks.

\section{DISCUSSION}

Almost no gender discrimination found among the PLHAs in Purba Medinipur district. But most of the PLHAs were less educated and illiterate. Most of them were young, adult and their income of the family was also stumpy. Highest number of the PLHAs became infected through heterosexual route and their profession was laborer (and home maker in case of women). It was observed that maximum PLHAs was found in the age group of 15 - 49 years (85\%) which was close to Indian scenario $89 \%{ }^{[7]}$. There was no gender difference among the PLHAs but in overall National finding men with PLHAs were more than women. ${ }^{7}$

Due to uneven development of rural areas, people had to move for work at different industrial areas.
Some of them were skilled labor and others were unskilled. They could not afford their family to live with them. They had a chance of sexual encounter with unknown people and due to illiteracy and ignorance as well as poverty they fail to practice safe sex and they acquired HIV infection. ${ }^{8}$

There was significant difference between urban and rural distribution of PLHAs. Most of the PLHA cases were from the rural areas though the concentration of PLHAs was higher in the proximity to the district head quarter. This finding was similar with the finding of National AIDS Control Organization (NACO). ${ }^{9}$ But a technical report revealed that there was no difference of PLHAs distribution between urban and rural area of India. ${ }^{10}$

Children became infected by the parents usually. But a few PLHAs child acquired infection during blood transfusion for thalassaemia. It was observed, most PLHAs were found in $15-45$ years $(84 \%)$ which was close to Indian scenario $88.7 \% .^{11}$ Heterosexual route of HIV transmission was found prevalent among the PLHAs. So it is important to counsel people about safe sex practice, awareness generation of HIV, its mode of transmission and prevention. It is necessary to improve social security, quality of life and opportunity of employment to the people to halt HIV spread.

\section{REFERENCES}

1. UNAIDS, WHO: AIDS Epidemic data, (unaids.org / pub / report / 2009 / jc1700_epi_updatee_en.pdf), Update, Dec. 2009.

2. World HIVIAIDS Statistics. Global HIV and AIDS estimates, 2009 and 2010 (www.avert.org/ worldstat.htm) 
3. UNAIDS, World AIDS Day Report 2011 (http:// www.unaids.org/en/media/unaids/contentassets/ documents/unaidspublication/2011/JC2216_ WorldAIDSday_report_2011_en.pdf)

4. National AIDS Control Organization, Department of AIDS Control; Ministry of Health \& Family Welfare, Government of India: Annual Report 2010-11, (http://www.nacoonline.org/upload/REPORTS/ NACO\%20Annual\%20Report\%202010-11.pdf)

5. National AIDS Control Organization, Ministry of Health and Family Welfare; Government of India, A Technical Brief HIV Sentinel Surveillance and HIV Estimation 20070ctober 2008, (http://www. nacoonline.org/upload/Publication/M\&E\%20 Surveillance,\%20Research/HIV\%20Sentinel\%20 Surveillance $\% 20$ and $\% 20$ HIV\%20Estimation $\% 20$ 2007_A\%20Technical\%20Brief.pdf)

6. Census of India 2001.

(http://www.censusindia.gov.in/2001-common/ censusdataonline.html)
7. National AIDS Control Organization, Department of AIDS Control; Ministry of Health and Family Welfare, Government of India, HIV Data. (www. nacoonline.org/Quick_Link/HIV_Data).

8. Ranjan Gupta. HIVIAIDS and the future of the poor, illiterate and marginalized population, Theoritical Division, Los Alamos National Laboratory, Los Alamos, NM 87545, USA; ranjan@lanl.gov

9. National AIDS Control Organization, Ministry of Health \& Family Welfare, Government of India, New Delhi, August 2009

10. The Technical Report: India HIV Estimate 2006, National AIDS Control Organization (NACO) and National Institute of Medical Statistics (NIMS).

11. HIV Sentinel Surveillance and HIV Estimation in India 2007, A Technical Brief, NACO, Ministry of H\&FW, Govt. India, October 2008. 